\title{
Jurist-Diction
}

Volume 1 No. 1, September 2018

Article history: Submitted 2 December 2018; Accepted 6 January 2019; Available online 27 January 2019

\section{KEWENANGAN HAKIM PRAPERADILAN STUDI KASUS NOMOR 24/PID/PRA/2018/PN.JKT.SE}

\author{
Eka Nanda Rahmat Jaya \\ ekanandarahmatjaya@gmail.com \\ Universitas Airlangga
}

\begin{abstract}
Forced effort is an authority possessed by investigators in helping carry out their duties as investigators of a case, the types of forced efforts are further regulated in the Criminal Procedure Code. To oversee the forced efforts of investigators, the district court made a pretrial institution whose job it was to assess whether the forced efforts made by investigators had fulfilled the formal requirements contained in the Criminal Procedure Code, this was in accordance with the mandate contained in Article 77 of the Criminal Procedure Code. But with the dynamics of problems and cases that are increasingly diverse this day, resulting in Judges as representatives of God on earth also innovating in giving pretrial decisions, but the innovation of pretrial decisions given by the Judge is not in accordance with the authority or can be said to exceed the authority (Ultra Vires) given by KUHAP. Moreover, against the decisions of pretrial judges that have exceeded Legal efforts cannot be sought, legal remedies which are prohibited in the Decision of the Constitutional Court Number 65 / PUU-IX / 2011, cassation in Article 45A of the Supreme Court Law Number 5 of 2004 and a review in a Circular Supreme Court Number 3 of 2014.
\end{abstract}

Keywords: Pretrial; Ultra Vires; Legal Efforts.

\begin{abstract}
Abstrak
Upaya Paksa adalah suatu kewenangan yang dimiliki oleh penyidik dalam membantu menjalankan tugasnya sebagai penyidik suatu kasus, macam - macam upaya paksa diatur lebih lanjut dalam KUHAP. Untuk mengawasi upaya paksa yang dimiliki oleh penyidik, pengadilan negeri membuat suatu Lembaga praperadilan yang tugasnya menilai apakah upaya paksa yang dilakukan penyidik telah memenuhi syarat formil yang tertuang dalam KUHAP, hal ini sesuai dengan amanat yang terkandung dalam Pasal 77 KUHAP. Akan tetapi dengan dinamika permasalahan dan kasus yang semakin hari semakin beragam ini, mengakibatkan Hakim sebagai wakil tuhan di bumi juga melakukan inovasi dalam memberikan putusan praperadilan, akan tetapi inovasi putusan praperadilan yang diberikan Hakim tidak sesuai dengan kewenangan atau bisa dikatakan melebihi kewenangan (Ultra Vires) yang diberikan oleh KUHAP. Terlebih, terhadap putusan hakim praperadilan yang telah melebihi kewenangan (Ultra Vires) ini tidak bisa dimintakan upaya hukum, baik upaya hukum banding yang dilarang dalam Putusan Mahkamah Konstitusi Nomor 65/PUU-IX/2011, kasasi dalam Pasal 45A Undang - Undang Mahkamah Agung Nomor 5 Tahun 2004 dan peninjauan kembali dalam Surat Edaran Mahkamah Agung Nomor 3 Tahun 2014.
\end{abstract}

Kata Kunci: Praperadilan; Ultra Vires; Upaya Hukum.

\section{Pendahuluan}

Proses acara pidana di Indonesia baik prosedur dan tata caranya diatur dalam Kitab Undang-Undang Hukum Acara Pidana (selanjutnya disebut KUHAP). "Hukum Acara Pidana yang berlaku pada saat ini adalah yang diatur 
di dalam Undang-Undang Nomor 8 Tahun 1981 yang ditetapkan pada tanggal 31 Desember 1981". ${ }^{1}$ Peradilan pidana di Indonesia pada hakekatnya merupakan suatu sistem, hal ini dikarenakan dalam proses peradilan pidana di Indonesia terdiri dari tahapan-tahapan yang merupakan satu kesatuan utuh yang tidak dapat dipisahkan. Tahapan-tahapan dalam proses peradilan pidana tersebut merupakan suatu rangkaian, dimana tahap yang satu mempengaruhi tahapan yang lain. Tahapan-tahapan dalam peradilan pidana di indonesia dibuat agar seorang aparat sebagai penegak hukum dalam melaksanakan kewajibannya tidak terlepas dari kemungkinan untuk berbuat sesuatu yang tidak sesuai dengan Undang-Undang yang berlaku, sehingga perbuatan yang dilakukan dengan tujuan untuk pemeriksaan demi terciptanya ketertiban dan keadilan masyarakat justru mengakibatkan kerugian bagi tersangka, keluarga tersangka, atau pihak ketiga yang berkepentingan. Kewenangan-kewenangan yang dimiliki oleh hakim, kejaksaan, dan kepolisian meskipun berbeda, tetapi pada prinsipnya merupakan satu kesatuan utuh yang tidak dapat dipisahkan.

Oleh sebab itu KUHAP menjamin terlindungnya hak-hak pelaku tindak pidana. Menurut Lilik Mulyadi, pada asasnya pengertian hukum acara pidana itu merupakan: ${ }^{2}$

1. Peraturan hukum yang mengatur, menyelenggarakan, dan mempertahankan eksistensi ketentuan hukum pidana materiil (materieel strafrecht) guna mencari, menemukan, dan mendapatkan kebenaran materiil atau yang sesungguhnya;

2. Peraturan hukum yang mengatur bagaimana cara dan proses pengambilan putusan oleh hakim;

3. Peraturan hukum yang mengatur tahap pelaksanaan daripada putusan yang diambil.

Yang dimaksud dengan praperadilan adalah wewenang Pengadilan Negeri untuk memeriksa dan memutus menurut cara yang diatur dalam Pasal 1 angka 10 KUHAP, tentang:

a. Sah atau tidaknya suatu penangkapan dan atau penahanan atas permintaan tersangka atau keluarganya atau pihak lain atas kuasa tersangka;

\footnotetext{
${ }^{1}$ C. Djisman Samosir, Segenggam tentang Hukum Acara Pidana (Nuansa Aulia 2013).[1].

${ }^{2}$ Lilik Mulyadi, Suatu Tinjauan Khusus Terhadap Surat Dakwaan, Eksepsi, dan Putusan Peradilan (Citra Aditya Bakti 2012).[4].
} 
b. Sah atau tidaknya penghentian penyidikan atau penghentian penuntutan atas permintaan demi tegaknya hukum dan keadilan;

c. Permintaan ganti kerugian atau rehabilitasi oleh tersangka atau keluarganya atau pihak lain atas kuasanya yang perkaranya tidak diajukan ke Pengadilan.

Menurut Pasal 77 KUHAP, Pengadilan Negeri berwenang untuk memeriksa dan memutus, sesuai dengan ketentuan yang diatur dalam undang-undang ini tentang:

a. Sah atau tidaknya penangkapan, penahanan, penghentian penyidikan atau penghentian penuntutan;

b. Ganti kerugian dan atau rehabilitasi bagi seorang yang perkara pidananya dihentikan pada tingkat penyidikan atau penuntutan.

Dengan adanya lembaga praperadilan ini, aparat penegak hukum dalam melakukan upaya paksa, yang maksudnya yaitu suatu kewenangan yang dimiliki oleh penyidik ataupun penuntut umum untuk mengurangi hak asasi yang dimiliki oleh tersangka, saksi, korban, ahli ataupun pelapor, dimana dalam upaya paksa ini setidaknya terdapat 6 macam yaitu penangkapan, penahanan, penggeledahan, penyitaan, pemeriksaan surat dan pemanggilan, terhadap seorang tersangka dan tetap bertindak berdasarkan undang - undang dan tidak bertentangan dengan hukum yang ada. Namun dalam penerapannya masih terdapat permasalahan yang menjadi pro-kontra, terutama mengenai penghentian penyidikan yang dijadikan sebagai objek praperadilan sebagaimana diatur pada Pasal 77 huruf a yang berbunyi: "Sah atau tidaknya penangkapan, penahanan, penghentian penyidikan atau penghentian penuntutan"

Berdasarkan latar belakang tersebut, maka dapat dirumuskan suatu permasalahan sebagai berikut :

1. Ruang lingkup Prapradilan pasca Putusan Nomor 24/Pid/Pra/2018/PN.Jkt.Sel

2. Apakah hakim praperadilan berwenang memberikan putusan praperadilan Nomor 24/Pid/Pra/2018/PN.Jkt.Sel yang mana hakim menetapkan tersangka baru? 


\section{Metode Penelitian}

Penelitian yang dilakukan adalah penelitian yuridis normatif atau biasa disebut dengan penelitian hukum yaitu suatu proses untuk menemukan aturan hukum, prinsip-prinsip hukum, maupun doktrin-doktrin hukum guna menjawab isu hukum yang dihadapi. ${ }^{3}$

Penulisan menggunakan pendekatan statue approach (pendekatan UndangUndang) dilakukan dengan menelaah segala peraturan perundang-undangan yang berlaku dan berkaitan dengan isu hukum yang diteliti. Dan pendekatan kasus dilakukan dengan cara melakukan telaah terhadap kasus-kasus yang berkaitan dengan isu yang dihadapi yang telah menjadi putusan pengadilan yang telah mempunyai kekuatan hukum tetap. Dalam menggunakan pendekatan kasus, yang perlu dipahami yaitu ratio decidendi, yaitu alasan-alasan hukum yang digunakan oleh hakim untuk sampai kepada putusannya. Menurut Goodheart, ratio decidendi dapat diketemukan dengan memperhatikan fakta materiil. Ratio decidendi inilah yang menunjukkan bahwa ilmu hukum merupakan ilmu yang bersifat preskriptif, bukan deskriptif. ${ }^{4}$

\section{Praperadilan dalam sistem hukum di Indonesia}

Menurut Hartono, Pengertian Praperadilan adalah proses persidangan sebelum sidang masalah pokok perkaranya disidangkan. Pengertian perkara pokok ini adalah perkara materinya, sedangkan dalam praperadilan proses persidangan hanya menguji proses tata cara penyidikan dan penuntutan, atau bisa dikatakan memeriksa rangkaian tindakan yang dilakukan oleh kepolisian sebelum dilimpahkan kepada Kejaksaan setempat. Contohnya : ketika menangkap tersangka korupsi, apakah yang ditangkap itu benar - benar pelaku korupsi sebagaimana dimaksud dalam laporannya. Selanjutnya, dalam penahanan atau apakah penahanan itu tidak melanggar hukum karena telah lewat waktu penahanannya, apakah keluarga tersangka juga sudah dikirimi pemberitahuan mengenai tindakan penangkapan dan

\footnotetext{
${ }^{3}$ Peter Mahmud Marzuki, Penelitian Hukum (Kencana Prenada Media Group 2005).[35].

${ }^{4}$ ibid.[158].
} 
tindakan penahanan bukan kepada materi pokoknya. Artinya praperadilan yaitu suatu proses yang mendahului proses pemeriksaan pokok perkara dan dikatakan proses yang bukan merupakan pemeriksaan pokok perkara.

Acara dalam pemeriksaan praperadilan ini diatur secara rinci di dalam Pasal 82 KUHAP yang berbunyi:

ayat (1) Acara pemeriksaan praperadilan untuk hal sebagaimana dimaksud dalam Pasal 79, Pasal 80 dan Pasal 81 ditentukan sebagai berikut :

a. dalam waktu tiga hari setelah diterimanya permintaan, hakim yang ditunjuk menetapkan hari sidang;

b. dalam memeriksa dan memutus tentang sah atau tidaknya penangkapan atau penahanan, sah atau tidaknya penghentian penyidikan atau penuntutan, permintaan ganti kerugian dan atau rehabilitasi akibat tidak sahnya penangkapan atau penahanan, akibat sahnya penghentian penyidikan atau penuntutan dan ada benda yang disita yang tidak termasuk alat pembuktian, hakim mendengar keterangan baik dari tersangka atau pemohon maupun dari pejabat yang berwenang;

c. pemeriksaan tersebut dilakukan secara cepat dan selambat-lambatnya tujuh hari hakim harus sudah menjatuhkan putusannya;

d. dalam hal suatu perkara sudah mulai. diperiksa oleh Pengadilan Negeri, sedangkan pemeriksaan mengenai permintaan kepada praperadilan belum selesai, maka permintaan tersebut gugur;

e. putusan praperadilan pada tingkat penyidikan tidak menutup kemungkinan untuk mengadakan pemeriksaan, praperadilan lagi pada tingkat pemeriksaan oleh penuntut umum, jika untuk itu diajukan permintaan baru.

Definisi Praperadilan secara normatif dirumuskan dalam Pasal 1 angka 10 KUHAP, yang menegaskan bawah Praperadilan adalah wewenang Pengadilan Negeri untuk memeriksa dan memutus :

1. Sah atau tidaknya suatu penangkapan atau penahanan;

2. Sah atau tidaknya penghentian penyidikan atau penghentian penuntutan;

3. Permintaan ganti rugi atau rehabilitasi oleh tersangka atau keluarganya atau pihak lain atau kuasanya yang perkaranya tidak diajukan ke Pengadilan.

Sehingga berdasarkan Pasal 1 angka 10, Pasal 77 KUHAP dan putusan Mahkamah Konstitusi Nomor 21/PUU-XII/2014. Pengadilan Negeri berwenang memeriksa permohonan praperadilan dengan objek sebagai berikut :

a. Sah atau tidaknya penangkapan, penahanan, penghentian penyidikan atau penghentian penuntutan; 
b. Ganti kerugian dan atau rehabilitasi bagi seorang yang perkara pidananya dihentikan pada tingkat penyidikan atau penuntutan;

c. Sah atau tidaknya penetapan tersangka, penggeledahan, dan penyitaan.

\section{Tugas, Fungsi dan Wewenang Hakim dalam Proses Peradilan Pidana}

Kekuasaan kehakiman adalah kekuasaan negara yang merdeka untuk menyelenggarakan peradilan guna menegakkan hukum dan keadilan berdasarkan Pancasila, demi terselengaranya negara hukum Republik Indonesia. ${ }^{5}$ Penyelenggaraan kekuasaan kehakiman dilakukan oleh sebuah Mahkamah Agung dan peradilan di bawahnya yaitu: ${ }^{6}$

1. Lingkungan peradilan umum;

2. Lingkungan peradilan agama;

3. Lingkungan peradilan militer;

4. Lingkungan peradilan tata usaha negara, serta oleh Mahkamah Konstitusi

Dan menurut Al. Wisnu Broto, yang dimaksud dengan Hakim adalah konkretisasi hukum dan keadilan secara abstrak, Bahkan ada yang menggambarkan hakim sebagai wakil tuhan di bumi untuk menegakkan hukum dan keadilan. ${ }^{7}$

Hakim di Indonesia dibedakan menjadi 2 yaitu:

1. Hakim Karir;

2. Hakim Non Karir (Ad Hoc) Pegertian Hakim Karir ini dijelaskan dalam penjelasan Pasal 1 ayat 5 UU Nomor 49 Tahun 2009 tentang Kekuasaan Kehakiman, yang berbunyi : "Hakim adalah hakim pada Mahkamah Agung dan hakim pada badan peradilan yang berada di bawahnya dalam lingkungan peradilan umum, lingkungan peradilan agama, lingkungan peradilan militer, lingkungan peradilan tata usaha negara, dan hakim pada Pengadilan khusus yang berada dalam lingkungan peradilan tersebut".

Sedangkan Hakim Non Karir dijelaskan dalam penjelasan Pasal 1 ayat 9 UU Nomor 49 Tahun 2009 tentang Kekuasaan Kehakiman, yang bunyinya : "Hakim ad hoc adalah hakim yang bersifat sementara yang memiliki keahlian dan pengalaman di bidang tertentu untuk memeriksa, mengadili, dan memutus

\footnotetext{
${ }^{5}$ Pasal 24 Undang-Undang Dasar Negara Republik Indonesia Tahun 1945 dan Pasal 1 Undang-Undang Nomor 48 Tahun 2009 tentang Kekuasaan Kehakiman (Lembaran Negara Republik Indonesia Tahun 2009 Nomor 157).

${ }^{6}$ ibid. [8].

${ }^{7}$ Al. Wisnu Broto, Hakim Dan Peradilan Di Indonesia (dalam beberapa aspek kajian) (Penerbitan Universitas Atma Jaya 1997).[2].
} 
suatu perkara yang pengangkatannya diatur dalam undangundang".

Sesuai dengan Pasal 10 ayat (1) Undang - Undang Nomor 48 tahun 2009 tetang Kekuasaan Kehakiman, Hakim sebagai organ utama dalam melaksanakan kekuasaan kehakiman dianggap memahami hukum untuk dapat menerima, memeriksa, dan mengadili suatu perkara, sehingga dengan ketentuan yang terdapat dalam Pasal ini, wajib hukumnya bagi Hakim untuk dapat menemukan hukum, baik melalui hukum tertulis maupun tidak tertulis untuk memutuskan suatu perkara berdasarkan hukum sebagai seorang yang bijaksana dan bertanggung jawab. Hal ini wajib dilaksanakan karena hakim dianggap orang yang tahu tentang aturan hukum (curialus Novit/ ius curia novit).

Dalam rangka menegakkan hukum dan keadilan, seorang hakim mempunyai kewajiban atau tanggung jawab hukum dalam mengemban amanahnya menjadi seorang hakim yang dijelaskan dalam Pasal - Pasal yang terdapat dalam Undang - Undang Nomor 48 tahun 2009 tentang Kekuasaan Kehakiman yang berbunyi :

1. Pasal 3 ayat (1), dalam menjalankan tugas dan fungsinya, hakim dan hakim konstitusi wajib menjaga kemandirian peradilan, yang dimaksud dengan menjaga kemandirian peradilan adalah dengan tidak boleh adanya campur tangan atau intervensi dari pihak lain dalam urusan peradilan, sebagaimana yang diamanatkan dalam Pasal 24 ayat (1) Undang - Undang Dasar Negara Republik Indonesia tahun 1945;

2. Pasal 5 ayat (1), hakim dan hakim konstitusi wajib menggali, mengikuti, dan memahami nilai-nilai hukum dan rasa keadilan yang hidup dalam masyarakat, sebagaimana yang dijelaskan dalam penjelasan Pasal ini bahwa ketentuan yang dimaksud agar putusan hakim dan hakim konstitusi sesuai dengan hukum dan rasa keadilan masyarakat;

3. Pasal 5 ayat (3), hakim dan hakim konstitusi wajib menaati Kode Etik dan Pedoman Perilaku Hakim, kode etik menjadi hal yang wajib karena hakim dituntut memiliki moralitas dan tanggung jawab yang tinggi, yang seluruhnya dituangkan dalam Keputusan Bersama Ketua Mahkamah Agung RI dan Ketua Komisi Yudisial RI Nomor : 047/KMA/SKB/IV/2009-02/SKB/P.KY/ IV/2009 Tentang Kode Etik Dan Pedoman Perilaku Hakim, antara lain:

a. Berperilaku Adil;

b. Berperilaku Jujur;

c. Berperilaku Arif dan Bijaksana;

d. Bersikap Mandiri;

e. Berintegritas Tinggi;

f. Bertanggung Jawab;

g. Menjunjung Tinggi Harga Diri; 
h. Berdisiplin Tinggi;

i. Berperilaku Rendah Hati;

j. Bersikap Profesional.

4. Pasal 8 ayat (2), Dalam mempertimbangkan berat ringannya pidana, hakim wajib memperhatikan pula sifat yang baik dan jahat dari terdakwa. Hakim wajib memperhatikan sifat baik atau sifat jahat dari terdakwa sehingga putusan yang dijatuhkan sesuai dan adil dengan kesalahan yang dilakukannya;

5. Pasal 14 ayat (2), Dalam sidang permusyawaratan, setiap hakim wajib menyampaikan pertimbangan atau pendapat tertulis terhadap perkara yang sedang diperiksa dan menjadi bagian yang tidak terpisahkan dari putusan;

6. Pasal 14 ayat (3), Dalam hal sidang permusyawaratan tidak dapat dicapai mufakat bulat, pendapat hakim yang berbeda wajib dimuat dalam putusan;

7. Pasal 17 ayat (3), Seorang hakim wajib mengundurkan diri dari persidangan apabila terikat hubungan keluarga sedarah atau semenda sampai derajat ketiga, atau hubungan suami atau istri meskipun telah bercerai, dengan ketua, salah seorang hakim anggota, jaksa, advokat, atau panitera;

8. Pasal 17 ayat (5), Seorang hakim atau panitera wajib mengundurkan diri dari persidangan apabila ia mempunyai kepentingan langsung atau tidak langsung dengan perkara yang sedang diperiksa, baik atas kehendaknya sendiri maupun atas permintaan pihak yang berperkara, yang dimaksud dengan "kepentingan langsung atau tidak langsung" adalah termasuk apabila hakim atau panitera atau pihak lain pernah menangani perkara tersebut atau perkara tersebut pernah terkait dengan pekerjaan atau jabatan yang bersangkutan sebelumnya.

\section{Tugas, Fungsi dan Wewenang Hakim dalam Praperadilan}

Terdapat beberapa hal baru yang belum pernah diatur sebelumnya di dalam IR atau HIR, yang sekarang baru tercantum dalam KUHAP, antara lain: ${ }^{8}$

1. Hak-hak tersangka dan terdakwa (Pasal $50 \mathrm{~s} / \mathrm{d} 68$ KUHAP);

2. Bantuan hukum pada setiap tingkat pemeriksaan (Pasal $69 \mathrm{~s} / \mathrm{d} 74 \mathrm{KUHAP}$ );

3. Penggabungan perkara perdata pada perkara pidana dalam hal ganti rugi (Pasal 98 s/d 101 KUHAP);

4. Pengawasan pelaksanaan Putusan Hakim (Pasal 277 s/d 283 KUHAP);

5. Wewenang hakim pada pemeriksaan pendahuluan yakni praperadilan (Pasal $77 \mathrm{~s} / \mathrm{d} 83$ KUHAP).

Pasal 78 ayat (2) KUHAP menjelaskan bahwa pemeriksaan sidang praperadilan dipimpin oleh hakim tunggal yang ditunjuk oleh Ketua Pengadilan Negeri dan dibantu oleh seorang panitera pengganti. KUHAP sendiri tidak menjelaskan mengapa sidang

\footnotetext{
${ }^{8}$ Loebby Loqman, Pra-peradilan di Indonesia (Galia Indonesia 1987).[7].
} 
praperadilan ini hanya cukup dipimpin oleh seorang hakim dan seorang panitera pengganti. Namun menurut penulis, hal ini dikarenakan prinsip yang terdapat dalam Pasal 82 ayat (1) huruf c KUHAP yang menyatakan bahwa pemeriksaan praperadilan tersebut dilakukan secara cepat dan selambat-lambatnya, dan dalam 7 (tujuh) hari hakim harus sudah menjatuhkan putusannya. Selain itu, bentuk putusan praperadilannya pun harus sederhana namun tidak boleh mengurangi dasar alasan pertimbangan yang utuh dan menyeluruh. Jika proses beracara dalam proses praperadilan tidak selesai dalam 7 (tujuh) hari maka perkara praperadilan dianggap gugur dan/atau telah dimulainya sidang pemeriksaan pokok perkara oleh Pengadilan Negeri.

Putusan hakim tersebut tidak sesuai dengan putusan Mahkamah Konstitusi Nomor 21/PUU-XII/2014 yang telah memperluas ketentuan dalam Pasal 77 KUHAP mengenai wewenang hakim praperadilan menjadi

1. Sah atau tidaknya penangkapan, penahanan, penghentian penyidikan dan penghentian penuntutan;

2. Ganti kerugian atau rehabilitasi bagi tersangka yang peraranya tidak diajukan ke pangadilan.

Upaya hukum kasasi juga dilarang di dalam Undang-Undang Mahkamah Agung Nomor 5 Tahun 2004 Pasal 45A yang menjelaskan bahwa:

(1) Mahkamah Agung dalam tingkat kasasi mengadili perkara yang memenuhi syarat untuk diajukan kasasi, kecuali perkara yang oleh Undang-Undang ini dibatasi pengajuannya;

(2) Perkara yang dikecualikan sebagaimana dimaksud pada ayat (1) terdiri atas: a) putusan tentang praperadilan;

b) perkara pidana yang diancam dengan pidana penjara paling lama 1 (satu) tahun dan/atau diancam pidana denda;

c) perkara tata usaha negara yang objek gugatannya berupa keputusan pejabat daerah yang jangkauan keputusannya berlaku di wilayah daerah yang bersangkutan.

(3) Permohonan kasasi terhadap perkara sebagaimana dimaksud pada ayat (2) atau permohonan kasasi yang tidak memenuhi syarat-syarat formal, dinyatakan tidak dapat diterima dengan penetapan ketua pengadilan tingkat pertama dan berkas perkaranya tidak dikirimkan ke Mahkamah Agung;

(4) Penetapan ketua pengadilan sebagaimana dimaksud pada ayat (3) tidak dapat diajukan upaya hukum. (5) Pelaksanaan ketentuan sebagaimana dimaksud pada ayat (3) dan ayat (4) diatur lebih lanjut oleh Mahkamah Agung." 
Sedangkan upaya hukum peninjauan kembali juga tidak dapat dilakukan, karena para Hakim Agung dan Panitera Pengganti Kamar Pidana dalam kesepakatan yang dituangkan dalam SEMA No 4 Tahun 2014 telah mengatur bahwa Peninjauan Kembali terhadap praperadilan tidak diperbolehkan kecuali dalam hal ditemukan indikasi penyelundupan hukum, lebih lanjut larangan upaya hukum Peninjauan Kembali ini diatur dalam PERMA Nomor 4 Tahun 2016 Tentang Larangan Peninjauan Kembali Putusan Praperadilan. Dalam Pasal 3 peraturan ini menjelaskan bahwa:

Ayat (1) menjelaskan bahwa putusan praperadilan tidak dapat diajukan Peninjauan Kembali

Ayat (2) Permohonan Peninjauan Kembali terhadap praperadilan dinyatakan tidak dapat diterima dengan penetapan Ketua Pengadilan Negeri dan berkas perkara tidak dikirim ke Mahkamah Agung

Ayat (3) Penetapan Ketua Pengadilan Negeri sebagaimana dimaksud pada ayat (1) tidak dapat diajukan upaya hukum.

Berdasarkan larangan - larangan ini, maka upaya hukum Banding, Kasasi, dan Peninjauan Kembali dalam perkara praperadilan ini sudah tertutup. Dalam hal ini, berkaitan dengan putusan praperadilan yang menyimpang secara fundamental, berdasarkan pasal 4 PERMANomor 4 Tahun 2016, MahkamahAgung dapat memberi petunjuk, teguran, atau peringatan terhadap hakim yang menjatukan putusan yang menyimpang tersebut. Dalam kasus ini, Mahkamah Agung telah melakukan demosi dikarenakan putusan yang dijatuhkan oleh hakim Effendi Mukhtar menyimpang secara fundamental. Hal ini bisa dilihat dari keterangan Ketua Mahkamah Agung, Hatta Ali, dalam berita online yang menyatakan bahwa demosi dilakukan karena Effendi dinilai tidak profesional karena mengeluarkan putusan untuk menetapkan eks Wapres Boediono sebagai tersangka bail out Bank Century. ${ }^{9}$

\section{Pembahasan Putusan Nomor 24/Pid.Pra/2018/PN.Jkt.Sel.}

Hakim dalam memeriksa perkara praperadilan berbeda dengan memeriksa perkara pidana pada umumnya, hakim dalam memeriksa perkara pidana berupaya

\footnotetext{
${ }^{9}$ Denita. Matondang, 'Ketua MA: Hakim PraperadilanBoediono didemosi karena bersalah', (Detik News, 2018) <https://news.detik.com/berita/d-3992153/ketua-ma-hakim-praperadilanboediono-didemosi-karena-bersalah>, accesed 25 Desember 2018.
} 
mencari dan membuktikan kebenaran materiil berdasarkan fakta-fakta yang terungkap dalam persidangan dan memegang teguh pada surat dakwaan yang dirumuskan oleh Penuntut Umum, sedangkan hakim dalam memeriksa perkara praperadilan hanya dapat memeriksa mengenai syarat formil dari suatu upaya paksa yang dilakukan oleh penyidik dan penuntut umum tanpa memperhatikan syarat materiil. Sebelum menguraikan mengenai putusan praperadilan nomor 24/Pid. Pra/2018/PN.Jkt.Sel, maka perlu diketahui terlebih dahulu posisi kasus.

\section{Analisa Putusan Nomor 24/Pid.Pra/2018/PN.Jkt.Sel.}

Dalam putusan praperadilan nomor 24/Pid.Pra/2018/PN.Jkt.Sel pada tanggal 9 April 2018 merupakan suatu putusan atas permohonan praperadilan atau merupakan bentuk implementasi kewenangan Pengadilan untuk memeriksa penghentian penyidikan, yang dalam putusan tersebut diajukan oleh Masyarakat Anti Korupsi Indonesia (MAKI) untuk Komisi Pemberantasan Korupsi (KPK) atas penghentian penyidikan terhadap Boediono, Muliaman D Hadad, Raden Pardede dkk. KPK telah melanggar beberapa ketentun, antara lain yaitu :

1. Pasal 5 UU No. 30 tahun 2002 Tentang Komisi Pemberantasan Korupsi, disebutkan "Dalam menjalankan tugas dan wewenangnya, Komisi Pemberantasan Korupsi berasaskan pada :

a. Kepastian hukum;

b. Keterbukaan;

c. Akuntabilitas;

d. Kepentingan umum; dan

e. Proporsionalitas".

2. Pasal 6 UU No. 30 tahun 2002 Tentang Komisi Pemberantasan Korupsi, disebutkan "Komisi Pemberantasan Korupsi mempunyai tugas :

a. Koordinasi dengan instansi yang berwenang melakukan pemberantasan tindak pidana korupsi;

b. Supervise terhadap instansi yang berwenang melakukan pemberantasan tindak pidana korupsi;

c. Melakukan penyelidikan, penyidikan, dan penuntutan terhadap tindak pidana korupsi;

d. Melakukan tindakan-tindakan pencegahan tindak pidana korupsi;

e. Melakukan monitor terhadap penyelanggaraan pemerintah negara”.

3. Pasal 25 UU No 31 tahun 1999 Tentang Pemberantasan Tindak Pidana Korupsi, disebutkan "Penyidikan, penuntutan dan pemeriksaan di sidang pengadilan dalam perkara tindak pidana korupsi harus didahulukan dari 
perkara lain guna penyelesaian secepatnya".

4. Pasal 50 KUHAP disebutkan;

1. Tersangka berhak segera mendapat pemeriksaan oleh penyidik dan selanjutnya dapat diajukan kepada penuntut umum;

2. Tersangka berhak perkaranya segera dimajukan ke pengadilan oleh penuntut umum;

3. Terdakwa berhak segera diadili oleh pengadilan".

5. 102 KUHAP;

1. Penyelidik yang mengetahui, menerima laporan atau pengaduan tentang terjadinya suatu peristiwa yang patut diduga merupakan tindak pidana wajib segera melakukan tindakan penyelidikan yang diperlukan;

2. Dalam hal tertangkap tangan tanpa menunggu perintah penyidik, penyelidik wajib segera melakukan tindakan yang diperlukan dalam rangka penyelidikan sebagaimana tersebut pada Pasal 5 ayat (1) huruf b;

3. Terhadap tindakan yang dilakukan tersebut pada ayat (1) dan ayat (2) penyelidik wajib membuat berita acara dan melaporkannya kepada penyidik sedaerah hukum".

6. 106 KUHAP disebutkan, "Penyidik yang mengetahui, menerima laporan atau pengaduan tentang terjadinya suatu peristiwa yang patut diduga merupakan tindak pidana wajib segera melakukan tindakan penyidikan yang diperlukan”.

Dalam petitum permohonannya, setidaknya terdapat satu permohonan

penetapan dan empat permohonan yang diajukan oleh pemohon (MAKI), antara lain yaitu :

1. Pemanggilan pejabat berwenang atas nama Saut Situmorang (Wakil Ketua KPK) guna didengar keterangan dalam pemeriksaan praperadilan aquo berdasar Pasal 82 ayat (1) huruf b KUHAP;

2. Menyatakan menerima dan mengabulkan permohonan PEMOHON untuk seluruhnya;

3. Menyatakan Pemohon sah kedudukannya sebagai pihak ketiga berkepentingan dan berhak mengajukan Permohonan Praperadilan dalam perkara a quo;

4. Menyatakan secara hukum TERMOHON telah melanggar ketentuan Pasal 5 dan 6 UU No. 30 tahun 2002 Tentang Komisi Pemberantasan Korupsi, Pasal 25 UU Pemberantasan Tindak Pidana Korupsi dan Pasal 50, 102 dan 106 KUHAP serta ketentuan perundang-undangan yang berlaku dalam menangani korupsi Bank Century, sehingga pelanggaran a quo merupakan bentuk penghentian penyidikan secara tidak sah dan batal demi hukum dengan segala akibat hukumnya atas perkara korupsi Bank Century berupa tidak ditetapkannya Boediono, Muliaman D Hadad, Raden Pardede dkk sebagai Tersangka dalam perkara korupsi Bank Century;

5. Memerintahkan TERMOHON untuk melakukan proses hukum selanjutnya sesuai dengan ketentuan hukum dan peraturan perundang-undangan yang berlaku atas dugaan tindak pidana korupsi Bank Century dalam bentuk melakukan penyidikan dan menetapkan tersangka terhadap Boediono, 
Muliaman D Hadad, Raden Pardede dkk dan melanjutkannya dengan pendakwaan dan penuntutan dalam proses persidangan di Pengadilan Tipikor Jakarta Pusat.

Dalam putusan praperadilan nomor 24/Pid.Pra/2018/PN.Jkt.Sel, hakim

Effendi Mukhtar mengabulkan permohonan pemohon untuk sebagian dengan ratio decidendi yang tertuang dalam pertimbangan hukumnya. Permohonan yang dikabulkan pertama yaitu Menyatakan Pemohon sah kedudukannya sebagai pihak ketiga berkepentingan dan berhak mengajukan Permohonan Praperadilan dalam perkara aquo, hakim berpendapat bahwa pemohon sah kedudukannya sebagai pihak ketiga berkepentingan dan berhak mengajukan permohonan praperadilan. Hal ini dikarenakan meskipun seluruh kaidah dalam Pasal 1917 BW (Burgelijk Wetboek) telah terpenuhi secara formal, tapi putusan praperadilan hanya memutus apakah secara formil proses yang dilakukan oleh penyidik dan belum memutus tentang pokok perkara yang harus diperiksa secara majelis, sehingga hakim berpendapat dalam suatu permohonan praperadilan tidak ada pembuktian tentang materi pokok perkara, sehingga tidak ada ne bis in idem dalam perkara praperadilan, sehingga dengan demikian pemohon sah kedudukannya sebagai pihak ketiga berkepentingan dan berhak mengajukan Permohonan Praperadilan dalam perkara aquo.

Permohonan kedua yang dikabulkan yaitu Memerintahkan TERMOHON untuk melakukan proses hukum selanjutnya sesuai dengan ketentuan hukum dan peraturan perundang-undangan yang berlaku atas dugaan tindak pidana korupsi Bank Century dalam bentuk melakukan penyidikan dan menetapkan tersangka terhadap Boediono, Muliaman D Hadad, Raden Pardede dkk dan melanjutkannya dengan pendakwaan dan penuntutan dalam proses persidangan di Pengadilan Tipikor Jakarta Pusat, hakim berpendapat bahwa, meskipun tidak sependapat dengan pemohon bahwa KPK telah melakukan penghentian penyidikan secara materiil, akan tetapi sebaliknya demi hukum dan keadilan serta perlindungan terhadap hak asasi manusia, KPK harus melanjutkan pemeriksaan dan penuntutan perkara ini secara tuntas terhadap nama-nama yang disebutkannya dalam dakwaan perkara Budi Mulya, apapun resikonya karena itulah konsekuensi logis yang harus dipertanggungjawabkan oleh KPK kepada masyarakat, bahwa dalam melakukan 
penegakan hukum tidak boleh melanggar prinsip-prinsip dan asas-asas hukum yang telah diakui dalam teori hukum pidana yang berlaku universal.

\section{Anotasi Hukum terhadap Putusan Praperadilan Nomor 24/Pid.Pra/2018/ PN.Jkt.Sel.}

Berdasarkan putusan praperadilan nomor 24/Pid.Pra/ 2018/PN.Jkt.Sel, terdapat dua permohonan yang diajukan oleh pemohon dan adapun juga pertimbangan hukum oleh hakim praperadilan atas permohonan pemohon dalam putusan praperadilan nomor 24/Pid.Pra/2018/PN.Jkt.Sel. Maka dengan hal tersebut, penulis menganalisis dasar permohonan dan pertimbangan hakim praperadilan\

Permohonan pertama, Menyatakan Pemohon sah kedudukannya sebagai pihak ketiga berkepentingan dan berhak mengajukan Permohonan Praperadilan dalam perkara aquo. Mengenai permohonan pertama ini, termohon mengemukakan bahwa permohonan praperadilan adalah Nebis in Idem, sehingga permohonan praperadilan aquo ini ditolak atau setidak-tidaknya harus dinyatakan tidak dapat diterima (niet ontvankelijke verklaard). Termohon berpendapat bahwa permohonan praperadilan yang diajukan pemohon saat ini (perkara nomor 24/Pid.Pra/2018/PN.Jkt.Sel tanggal 01 Maret 2018) ini adalah sama dengan perkara praperadilan nomor 12/ Pid.Pra/2016/PN.Jkt.Sel. yang putusan hakim menolak permohonan praperadilan pemohon untuk seluruhnya dan telah berkekuatan hukum tetap, dengan subyek maupun obyek perkara, yaitu :

a. Pemohon (MAKI);

b. Termohon (KPK);

c. Obyek permohonan terkait penghentian penyidikan secara materiil tidak sah dalam penanganan perkara Bank Century.

Hal ini juga diperkuat dengan pendapat hukum dari M. Yahya Harahap, S.H dalam bukunya yang berjudul Hukum Acara Perdata tentang Gugatan, Persidangan, Penyitaan, Pembuktian dan Putusan pengadilan halaman 439 yang menyatakan bahwa : "Ne Bis In Idem disebut juga excptive van gewijsde zaak yang berarti bahwa sebuah perkara dengan obyek sama, yang diputus oleh pengadilan yang 
berkekuatan tetap / yang sudah memiliki kekuatan yang mengikat oleh badan peradilan yang berwenang".

Selain itu, asas ne bis in idem mutlak untuk diterapkan oleh hakim dalam memeriksa suatu perkara yang sama dengan perkara terdahulu sebagaimana kaidah hukum Putusan Mahkamah Agung, Putusan Mahkamah Agung No. 588K/Sip/1973 tanggal 03 Oktober 1973, yang menyatakan sebagai berikut : "Karena perkara ini sama dengan perkara yang terdahulu, baik mengenai gugatannya maupun obyekobyek perkara dan juga penggugat-penggugatnya, yang telah mendapat keputusan dari Mahkamah Agung (Putusan tanggal 19 Desember 1970 No. 350 K/Sip/1970), seharusnya gugatan dinyatakan tidak dapat diterima."

Berdasarkan pendapat termohon diatas, hakim berpendapat bahwa terhadap jawaban termohon tersebut hakim praperadilan berpendapat bahwa putusan praperadilan hanya memutus apakah secara formil proses yang dilakukan oleh penyidik dan belum memutus tentang pokok perkara yang harus diperiksa secara majelis, sehingga hakim berpendapat dalam suatu permohonan praperadilan tidak ada pembuktian tentang materi pokok perkara, sehingga tidak ada Ne Bis In Idem dalam perkara praperadilan.

Penulis sependapat dengan pendapat yang diberikan oleh hakim praperadilan nomor 24/Pid.Pra/2018/PN.Jkt.Sel, hal ini dikarenakan memang proses praperadilan hanyalah proses pemeriksaaan administratif mengenai tata cara penyidik menetapkan seseorang sebagai tersangka, bukan memeriksa materi pokoknya. Sehingga tidak ada ne bis in idem, hal ini juga diperkuat dengan pendapat dari ahli hukum acara pidana Universitas Indonesia Luhut MP Pangaribuan kepada hukumonline, alasan ne bis in idem tidak relevan dipakai dalam praperadilan atas penetapan status tersangka kedua kali, sebab praperadilan tidak berhubungan dengan perkara pokok/substansi perkara. Ne Bis In Idem relevan dengan substansi bukan dengan cara yang merupakan yurisdiksi pengadilan.

Permohonan kedua, Memerintahkan TERMOHON untuk melakukan proses hukum selanjutnya sesuai dengan ketentuan hukum dan peraturan perundangundangan yang berlaku atas dugaan tindak pidana korupsi Bank Century dalam bentuk melakukan penyidikan dan menetapkan tersangka terhadap Boediono, 
Muliaman D Hadad, Raden Pardede dkk dan melanjutkannya dengan pendakwaan dan penuntutan dalam proses persidangan di Pengadilan Tipikor Jakarta Pusat. Mengenai permohonan kedua ini, hakim tunggal Effendi Mukhtar tidak sependapat dengan permohonan PEMOHON bahwa KPK telah melakukan penghentian penyidikan secara materiil, akan tetapi sebaliknya demi hukum dan keadilan serta perlindungn terhadap hak asasi manusia, KPK harus melanjutkan pemeriksaan dan penuntutan perkara ini secara tuntas terhadap nama-nama yang disebutkannya dalam dakwaan perkara Budi Mulya, apapun resikonya.

Hakim praperadilan berpendapat sesuai dengan keterangan ahli dari termohon Adnan Pasliaja dalam perkara terdahulu yang mengatakan bahwa, sehingga yang diperlukan adalah kesadaran dari termohon untuk bisa lebih cepat memulai penyelidikan dan/atau penyidikan kasus tersebut dan melimpahkannya ke penuntut umum apabila memenuhi syarat untuk dituntut dan disidangkan atau sebaliknya menghentikan penyelidikan kalau tidak ditemukan bukti yang cukup, dan dengan demikian ada kejelasan dan kepastian hukum atas kasus tersebut. Sejalan dengan pendapat ahli tersebut, maka hakim praperadilan berpendapat bahwa daripada KPK digugat praperadilan berkali-kali dan selalu menjawab dengan jawaban yang sama bahwa KPK masih terus mendalami dan mengumpulkan bukti-bukti dan karena KPK tidak bisa menerbitkan surat penghentian penyidikan (SP3) yang waktunya tidak jelas, dan yang sampai saat ini sudah tiga tahun sejak perkara Budi Mulya berkekuatan hukum tetap, maka akan lebih terhormat dan elegant bila KPK melimpahkan perkara tersebut ke Penuntut umum kejaksaan atau kepolisian.

Pendapat hakim tunggal ini didasarkan pada Pasal 44 ayat (4) Undang-Undang Nomor 30 Tahun 2002 Tentang Komisi Pemberantasan Korupsi, menyebutkan bahwa perkara tersebut diteruskan, Komisi Pemberntasan Korupsi melaksanakan penyidikan sendiri atau dapat melimpahkan perkara tersebut kepada penyidik kepolisian atau kejaksaan, dan pada ayat (5) dalam hal penyidikan dilimpahkan kepada kepolisian atau kejaksaan sebagaimana dimaksud pada ayat (4), kepolisian atau kejaksaan wajib melaksanakan koordinasi dan melaporkan perkembangan penyidikan kepada Komisi Pemberantasan Korupsi. 
Dengan pertimbangan ini, biarlah kepolisian dan/atau kejaksaan yang melanjutkan pengusutan penyelidikan dan penyidikan kasus Bank Century untuk pada masa mendatang, dan apabila kepolisian atau kejaksaan berpendapat penyidikan harus dihentikan sesuai dengan Pasal 109 ayat (2) KUHAP yaitu karena tidak terdapat cukup bukti, bukan merupakan tindak pidana, dan penyidikan dihentikan demi hukum, maka penyidik kepolisian dan atau kejaksaan bisa menerbitkan surat penghentian penyidikan (SP3), sehingga ada kejelasan teradap perkara ini. Akan tetapi, apa yang diputuskan hakim tunggal Effendi Mukhtar ini tidak sesuai dengan wewenang pengadilan negeri untuk mengadili perkara praperadilan dalam Pasal 2 ayat (1) Peraturan Mahkamah Agung Republik Indonesia Nomor 4 Tahun 2016 Tentang Larangan Peninjauan Kembali Putusan Praperadilan yang selanjutnya disingkat PERMA Nomor 4 Tahun 2016.

Dalam Pasal 2 ayat (1) PERMA Nomor 4 Tahun 2016 Tentang Larangan Peninjauan Kembali Putusan Praperadilan, menjelaskan tentang kewenangan pengadilan negeri untuk memeriksa dan memutus obyek praperadilan tentang:

a. sah atau tidaknya penangkapan, penahanan, penghentian penyidikan atau penghentian penuntutan, penetapan tersangka, penyitaan dan penggeledahan;

b. ganti kerugian dan atau rehabilitasi bagi seseorang yang perkara pidananya dihentikan pada tingkat penyidikan atau penuntutan.

Permohonan kedua tentang "Memerintahkan TERMOHON untuk melakukan proses hukum selanjutnya sesuai dengan ketentuan hukum dan peraturan perundangundangan yang berlaku atas dugaan tindak pidana korupsi Bank Century dalam bentuk melakukan penyidikan dan menetapkan tersangka terhadap Boediono, Muliaman D Hadad, Raden Pardede dkk dan melanjutkannya dengan pendakwaan dan penuntutan dalam proses persidangan di Pengadilan Tipikor Jakarta Pusat". yg dikabulkan hakim tunggal Effendi Mukhtar dalam perkara praperadilan nomor 24/Pid.Pra/2018/PN.Jkt.Sel ini tidak sesuai dengan kewenangan pengadilan negeri untuk memeriksa dan memutus suatu perkara praperadilan, atau bisa dikatakan hakim praperadilan telah melampau batas kewenangan yang diatur oleh Undang-Undang (Ultra Vires). Hal ini bisa dilihat dari bunyi putusan yang "Memerintahkan termohon untuk menetapkan tersangka". 
Menurut pendapat dari penulis, hakim tunggal praperadilan Effendi Mukhtar tidak bisa memberikan putusan yang memerintah termohon (KPK) untuk menetapkan tersangka, karena memang bukan kewenangan hakim praperadilan untuk memutus seperti ini, dan juga tidak ada konsekuensinya jika penyidik KPK tidak melakukan perintah dari hakim praperadilan tersebut. Hal ini senada dengan pendapat ahli hukum pidana Universitas Trisakti Abdul Fickar Hadjar "Putusan yang melebihi kewenangan bersifat tidak mengikat dan tidak wajib untuk diikuti”.

Penetapan tersangka adalah kewenangan mutlak yang diatur dalam Pasal 66 ayat (1) dan (2) Peraturan Kapolri Nomor 12 Tahun 2009 tentang Pengawasan dan Pengendalian Penanganan Perkara Pidana di Lingkungan Kepolisian Negara Republik Indonesia, selanjutnya disebut Perkap No. 12 tahun 2009 disebutkan bahwa:

1. Status sebagai tersangka hanya dapat ditetapkan oleh penyidik kepada seseorang setelah hasil penyidikan yang dilaksanakan memperoleh bukti permulaan yang cukup yaitu paling sedikit 2 (dua) jenis alat bukti

2. Untuk menentukan memperoleh bukti permulaan yang cukup yaitu paling sedikit 2 (dua) jenis alat bukti sebagaimana dimaksud pada ayat (1) ditentukan melalui gelar perkara.

Setelah penyidik berhasil mengumpulkan sekurang-kurangnya dua alat bukti, dan telah membuat terang tentang tindak pidana yang terjadi, baru penyidik melimpahkan kepada penuntut umum untuk melakukan penuntutan. Sedangkan putusan hakim praperadilan tersebut jelas-jelas telah memerintahkan untuk menetapkan tersangka terhadap Boediono, Muliaman D Hadad, Raden Pardede dkk. Artinya Boediono, Muliaman D Hadad, Raden Pardede dkk ini lebih dulu ditetapkan sebagai tersangka lebih dahulu, kemudian baru dilakukan proses penyelidikan dan penyidikan. Tahapan yang dperintahkan oleh hakim tunggal Effendi Mukhtar ini tidak sesuai dengan tahapan dalam KUHAP dan akan membawa ke praktik penegakan hukum masa lalu yang tidak sehat. Meskipun pertimbangan hakim adalah untuk keadilan dan kepastian hukum dan demi perlindungan terhadap hak asasi manusia. 


\section{Kesimpulan}

Hakim praperadilan memiliki tugas, fungsi dan wewenang yang sama seperti halnya hakim dalam peradilan umum, tetapi yang membedakan disini adalah, hakim praperadilan memiliki kewenangan dan batasan-batasan yang diatur secara limitatif dalam Pasal 77 KUHAP, dan Putusan Mahkamah Konstitusi Nomor 24/ PUU-XII/2014 mengenai tugas, fungsi dan kewenangan yang dapat dilakukan oleh hakim praperadilan.

Dalam salah satu amar putusan praperadilan nomor 24/Pid.Pra/2018/ PN.Jkt.Sel. Hakim Effendi Mukhtar memberikan putusan yang bunyinya adalah menetapkan tersangka terhadap Boediono, Muliaman D Hadad, Raden Pardede dkk. Namun menetapkan tersangka disini bukan merupakan kewenangan yang dimiliki oleh Hakim praperadilan, hakim praperadilan hanya dapat memeriksa apakah penetapan tersangka yang dilakukan penyidik telah memenuhi syarat formil atau belum. Penetapan tersangka adalah mutlak kewenangan dari penyidik, jadi seharusnya demi kepastian hukum, hakim tidak dapat memberikan putusan seperti apa yang ada dalam putusan praperadilan nomor 24/Pid.Pra/2018/PN.Jkt.Sel.

\section{Daftar Bacaan}

\section{Buku}

Alfiah, Nurul Ratna Praperadilan dan Ruang Lingkupnya (Akademika Pressindo 1986).

Djisman, C Samosir, Segenggam tentang Hukum Acara Pidana (Nuansa Aulia 2013).

Endro, Didik Purwoleksono, Hukum Acara Pidana (Airlangga University Press 2015).

Hamzah, Andi, Hukum Acara Pidana Indonesia (Sinar Grafika 2008).

Hartono, Penyidikan dan Penegakan Hukum Pidana (Melalui Pendekatan Hukum Progresif) (Sinar Grafika 2010).

Kuffal, HMA, Penerapan KUHAP dalam Praktik Hukum (UMM Press 2011). 
Loqman, Loebby, Pra-peradilan di Indonesia (Galia Indonesia 1987).

Mahmud, Peter Marzuki, Penelitian Hukum (Kencana Prenada Media Group 2005).

Mochamad, H.A.K Anwar, Chalimah Suyanto, dan Sunanto, Praperadilan (IndHill-Co 1989).

Mulyadi, Lilik, Suatu Tinjauan Khusus Terhadap Surat Dakwaan, Eksepsi, dan Putusan Peradilan (PT Citra Aditya Bakti 2012).

Nurul, Ratna Alfiah, Praperadilan dan Ruang Lingkupnya (Akademika Pressindo 1986).

Sasangka, Hari, Penyidikan, Penahanan, Penuntutan, dan Praperadilan dalam Teori dan Praktek (CV Mandar Maju 2007).

Sofyan, Andi dan Abd Asis, Hukum Acara Pidana - Suatu Pengantar (Kencana 2014).

Soeparmono, R, Praperadilan Dan Penggabungan Perkara Ganti Kerugian Dalam KUHAP (CV Mandar Maju 2003).

Sudikno, Bab-Bab Tentang Penemuan Hukum (PT Citra Aditya Bakti 2013).

Tjitrosoebono, Harjono, Komentar DPP Peradin Terhadap KUHAP (1987).

Waluyo, Bambang, Implementasi Kekuasaan Kehakiman Republik Indonesia (Sinar Grafika 1992).

Wisnu, Al Broto, Hakim Dan Peradilan Di Indonesia (dalam beberapa aspek kajian) (Universitas Atma Jaya 1997).

Yahya, M Harahap, Pembahasan Permasalahan dan Penerapan KUHAP, Pemeriksaan Sidang Pengadilan, Banding, Kasasi, dan Peninjauan Kembali (Sinar Grafika 2000).

HOW TO CITE: Eka Nanda Rahmat Jaya, 'Kewenangan Hakim Praperadilan Studi Kasus Nomor 24/Pid/Pra/2018/PN.Jkt.SE' (2019) Vol. 2 No. 1 Jurist-Diction. 